\title{
Synergistic effects of cisplatin-caffeic acid induces apoptosis in human cervical cancer cells via the mitochondrial pathways
}

\author{
AMONRAT KORANEEKIT ${ }^{1}$, TEMDUANG LIMPAIBOON ${ }^{1}$, ARUNNEE SANGKA $^{2}$, \\ PATCHAREE BOONSIRI ${ }^{3}$, SAKDA DADUANG $^{4}$ and JUREERUT DADUANG ${ }^{1}$ \\ ${ }^{1}$ Centre for Research and Development of Medical Diagnostic Laboratories; ${ }^{2}$ Department of Clinical Microbiology, \\ Faculty of Associated Medical Sciences; ${ }^{3}$ Department of Biochemistry, Faculty of Medicine; \\ ${ }^{4}$ Division of Pharmacognosy and Toxicology, Faculty of Pharmaceutical Sciences, \\ Khon Kaen University, Khon Kaen 40002, Thailand
}

Received July 11, 2016; Accepted November 7, 2017

DOI: $10.3892 / \mathrm{ol} .2018 .8256$

\begin{abstract}
Cervical cancer $(\mathrm{CxCa})$ is a major health problem globally and is associated with the presence of human papillomavirus infection. Cisplatin (CDDP) is a platinum-based chemotherapeutic agent. Owing to its side effects and drug-resistance, novel anticancer agents with lower toxicity, including caffeic acid (CFC), are of interest. However, the effects of CDDP and CFC in combination are, to the best of our knowledge, uninvestigated. The present study investigated the effectiveness of CDDP and $\mathrm{CFC}$ in combination and its mechanism of action on four human cervical cancer cell lines, which were compared with the Chlorocebus sabaeus normal kidney Vero cell line. Cell viability was evaluated using a sulforhodamine B assay. Caspase-Glo assay kits, measuring the activity of caspases-3, -7, -8 and -9, were used to detect caspase activation in HeLa and CaSki cell lines in response to CDDP and CFC in combination. The results revealed that $\mathrm{CDDP}$ and $\mathrm{CFC}$ alone reduced the proliferation of HeLa, CaSki, SiHa and C33A cell lines. Treatment with CFC exhibited no significant cytotoxicity towards Vero cells. In addition, CDDP-CFC significantly inhibited cell growth of HeLa and CaSki cell lines. In HeLa and CaSki cell lines, a combination index $<1$ for CDDP and CFC indicated the synergistic growth inhibition; the combination of the two also significantly increased expression of caspase- $3,-7$ and -9 . In conclusion, CFC may be a candidate anticancer agent that, when use in combination, may increase the therapeutic efficacy of CDDP.
\end{abstract}

Correspondence to: Dr Jureerut Daduang, Centre for Research and Development of Medical Diagnostic Laboratories, Faculty of Associated Medical Sciences, Khon Kaen University, 123 Mittraphap Road, Khon Kaen 40002, Thailand

E-mail: jurpoo@kku.ac.th

Abbreviations: $\mathrm{CxCa}$, cervical cancer; CDDP, cisplatin; $\mathrm{CFC}$, caffeic acid; SRB, sulforhodamine B

Key words: cervical cancer, apoptosis, synergistic effects, caffeic acid, cisplatin, phytochemicals

\section{Introduction}

Cervical cancer $(\mathrm{CxCa})$ was the fourth most common cancer amongst women globally in 2012 (1). The major cause of $\mathrm{CxCa}$ is infection with human papillomavirus (HPV). HPV-16 and -18 are high-risk HPV subtypes (2). The platinum-based antitumor agent cisplatin (CDDP) is a chemotherapeutic agent for the treatment of epithelial malignancies, including cervical (3), lung (4), ovarian (5) and testicular cancer (6). CDDP modifies DNA primarily at the N7-position of guanosine, causing inter- and intra-strand cross-links (7) and thus apoptosis (8). The clinical use of CDDP is often limited owing to its severe adverse effects (9) and the generation of chemoresistance (10).

Plants are major sources of phytochemicals. Polyphenolic compounds are involved in induction of apoptosis, growth arrest, inhibition of DNA synthesis and modulation of signal transduction pathways in cancer cells (11-13). Prior studies have demonstrated that phytochemicals have anti-oxidative (14), anti-inflammatory (15) and anticancer (16) activities. The use of phytochemicals for the treatment of cancer may enhance the efficacy of chemotherapy, lowering toxicity to normal cells. Therefore, phytochemicals in combination with CDDP may reduce the side effects caused by CDDP treatment alone. A previous study reported that tea polyphenols enhance the effect of CDDP in cervical cancer cells via the induction of apoptosis (17). Caffeic acid (CFC) is a simple phenolic compound (Fig. 1) identified primarily in coffee and specific herbs, particularly thyme, sage and spearmint (18). It was reported that CFC interacted synergistically with 5-fluorouracil (5-FU), leading to a reduction of apoptosis in HeLa cell line with minimum amount of hemolytic activity (19). Considering the aforementioned, CDDP and CFC were selected and their $\mathrm{CxCa}$ anticancer activity was assessed in combination.

\section{Materials and methods}

Reagents. CDDP was obtained from Masu Co., Ltd. (Bangkok, Thailand). CFC was obtained from Merck KGaA (Darmstadt, Germany). DMEM-high glucose medium, fetal bovine serum (FBS) and trypsin-EDTA were obtained from Gibco; Thermo Fisher Scientific, Inc. (Waltham, MA, USA). 
Cell lines and cell culture. Four cell lines, HeLa (HPV-18-positive), SiHa and CaSki (HPV-16-positive), and C33A (HPV-negative) cervical cancer cells and normal monkey epithelial kidney Vero cells were maintained at $37^{\circ} \mathrm{C}$ with $5 \% \mathrm{CO}_{2}$ in DMEM-high glucose medium supplemented with $10 \%$ FBS. Once the cells were $\sim 80 \%$ confluent, they were trypsinized with $1 \mathrm{ml}$ of $1 \mathrm{X}$ trypsin-EDTA, incubated at $37^{\circ} \mathrm{C}$ for $5 \mathrm{~min}$ and centrifuged at $250 \mathrm{x}$ g for $5 \mathrm{~min}$ at room temperature. The supernatant was then removed, and $200 \mu 1$ of seeding cells were resuspended in $4 \mathrm{ml}$ of DMEM-high glucose medium. Under these conditions, cells reached confluence in 3 days. Cells were then treated with the test compounds.

In vitro cytotoxicity assay. The in vitro cytotoxic effect of the test compounds was determined using a sulforhodamine B (SRB) assay (20). Briefly, cell lines $\left(6 \times 10^{3}\right.$ cells/well) were seeded in a 96-well plate for $24 \mathrm{~h}$ (day 0). Next, these cells were treated with various concentrations of $\operatorname{CDDP}(2,4,6,8$, $10,12,14,16,18$ and $24 \mu \mathrm{M})$ and CFC $(20,50,100,200,400$ and $800 \mu \mathrm{M}$ ) for $24 \mathrm{~h}$. Cells treated with $1 \%$ dimethyl sulfoxide (DMSO) were used as a negative control. Following this, cells were incubated at $37{ }^{\circ} \mathrm{C}$ with $5 \% \mathrm{CO}_{2}$ for $24 \mathrm{~h}$, medium was replaced with $100 \mu \mathrm{l}$ cold $10 \%$ (w/v) trichloroacetic acid in each well, and plates were incubated at $4^{\circ} \mathrm{C}$ for $1 \mathrm{~h}$. Next, the plates were washed four times with tap water and excess water was removed by paper towels and was completed dried using a blow dryer or air-dried at room temperature. Next, $100 \mu \mathrm{l}$ of $0.057 \%$ (w/v) SRB solution was added to each well and left at room temperature for $1 \mathrm{~h}$. Following this, the plates were quickly rinsed four times with $1 \%$ (v/v) acetic acid, $200 \mu \mathrm{l}$ of $10 \mathrm{mM}$ Tris base solution ( $\mathrm{pH} 10.5)$ was added to each well and the plates were shaken on a gyratory shaker for $1 \mathrm{~h}$. Finally, the optical density (OD) of solution in the plates was measured using a microplate reader at $510 \mathrm{~nm}$. Each concentration of drug treatment was repeated for three independent experiments. Cell viability was calculated by using the following formula: Cell viability $(\%)=\left[\left(\right.\right.$ mean $\mathrm{OD}_{\text {sample }}-$ mean $\left.\mathrm{OD}_{\text {day0 }}\right) /\left(\right.$ mean $\mathrm{OD}_{\text {negative control }}$-mean $\left.\left.\mathrm{OD}_{\text {day0 }}\right)\right]$ x100.

For the half-maximal inhibitory concentration determination $\left(\mathrm{IC}_{50}\right)$, a dose-response curve between the compound concentration and percent cell viability was plotted. The cytotoxicity of the test compounds was compared between the $\mathrm{CxCa}$ and Vero cell lines.

Estimation of combination index (CI). To estimate the CI of CDDP-CFC, the concentration of CDDP and CFC used in this experiment was a series of 1.5 -fold dilutions of $\mathrm{IC}_{50}$ values. In the present study, HeLa cells were treated with CDDP-CFC at various concentrations (3.25 and 88.88, 4.88 and 133.31, 7.32 and 200, 11 and 300, and 16.5 and $450 \mu \mathrm{M}$ CDDP and CFC, respectively), CaSki cells were treated with $\mathrm{CDDP}-\mathrm{CFC}$ at the following concentrations: (3.25 and 59.27, 4.88 and 88.88, 7.32 and 133.31, 11 and 200, and 16.5 and $300 \mu \mathrm{M}$ CDDP and CFC, respectively), and Vero cells were treated with $\mathrm{CDDP}-\mathrm{CFC}$ at various concentrations (3.25 and 88.88, 4.88 and 133.31, 7.32 and 200, 11 and 300, 16.5 and 450, and 24.7 and 675 $\mu \mathrm{M} \mathrm{CDDP}$ and $\mathrm{CFC}$, respectively). After $24 \mathrm{~h}$, cell growth was examined using the SRB assay. The effect of CDDP-CFC, quantified by determining CI, was performed using the Chou-Talalay algorithm (21) using CalcuSyn software (version 1.1; Biosoft,

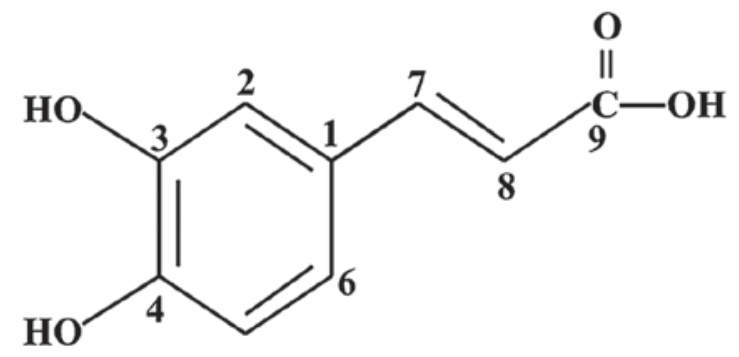

Figure 1. Chemical structure of caffeic acid.

Cambridge, UK). A CI value of 1 indicates an additive effect, $\mathrm{CI}<1$ represents synergism and $\mathrm{CI}>1$ represents antagonism. The dose reduction index (DRI), which is defined as the degree of dose reduction possible in a combination for a given degree of effect, compared with the dose of each drug alone, was also calculated using this software.

Caspases activity assay. Apoptosis pathway analysis was performed by observing caspase activity using Caspase-Glo-3/7, -8 and -9 assay kits (Promega Corporation, Madison, WI, USA). Cell lines (6x10 cells) in $100 \mu \mathrm{l}$ of media were seeded into 96-well plates. CDDP alone $(11 \mu \mathrm{M}), \mathrm{CFC}$ (300 $\mu \mathrm{M})$ and CDDP $(11 \mu \mathrm{M})$ or CFC alone $(200 \mu \mathrm{M})$ was added to $\mathrm{HeLa}$ and $\mathrm{CaSki}$ cells, which were incubated at $37^{\circ} \mathrm{C}$ for $24 \mathrm{~h}$. A total of $100 \mu \mathrm{l}$ Caspase-Glo-3/7, -8 and -9 reagents were then added, the plates were shaken for $30 \mathrm{sec}$, followed by incubation at room temperature for $1 \mathrm{~h}$. For the negative control, no CDDP or CFC was added. The blank control contained Caspase-Glo-3/7, -8 and -9 reagents without cells and CDDP-CFC. Following this, luminescent signal was detected by using a SpectraMax L Luminescence microplate reader (Molecular Devices, LLC, Sunnyvale, CA, USA). The data was analyzed using Soft Max ${ }^{\circledR}$ Pro software (version 6.2.2; Molecular Devices, LLC, CA, USA).

Statistical analysis. Data are expressed as the mean \pm standard deviation (SD). The differences between testing groups were determined using Tukeys post hoc test following one-way analysis of variance. $\mathrm{P}<0.05$ was considered to indicate a statistically significant difference. All analyses were performed using SPSS (version 17; SPSS Inc., Chicago, IL, USA). The correlation coefficient, CI and DRI were calculated using CalcuSyn software (version 1.1; Biosoft, Cambridge, UK).

\section{Results}

Cytotoxicity of CDDP and CFC on cervical cancer cell lines. CDDP and CFC significantly inhibited the growth of $\mathrm{CxCa}$ cell lines (Fig. 2). $\mathrm{IC}_{50}$ of CDDP in HeLa, CaSki, SiHa, C33A and Vero cells was $12 \pm 1.57,10 \pm 0.00,13 \pm 13.32,10 \pm 0.50$ and $18 \pm 1.22 \mu \mathrm{M}$, respectively. All $\mathrm{CxCa}$ cell lines, other than HeLa, had a significant lower $\mathrm{IC}_{50}$ for CDDP than did Vero cells. The results in Fig. 2 show that CFC significantly inhibited the growth of HeLa, CaSki, SiHa, C33A and Vero cells, with $\mathrm{IC}_{50}$ values of $327 \pm 11.55,220 \pm 18.03,157 \pm 15.28,40 \pm 3.21$ and $487 \pm 30.55 \mu \mathrm{M}$, respectively. In the present study, a $1 \%$ concentration of DMSO was tested in each of the cell lines. The results demonstrated that the percentage of cell viability 

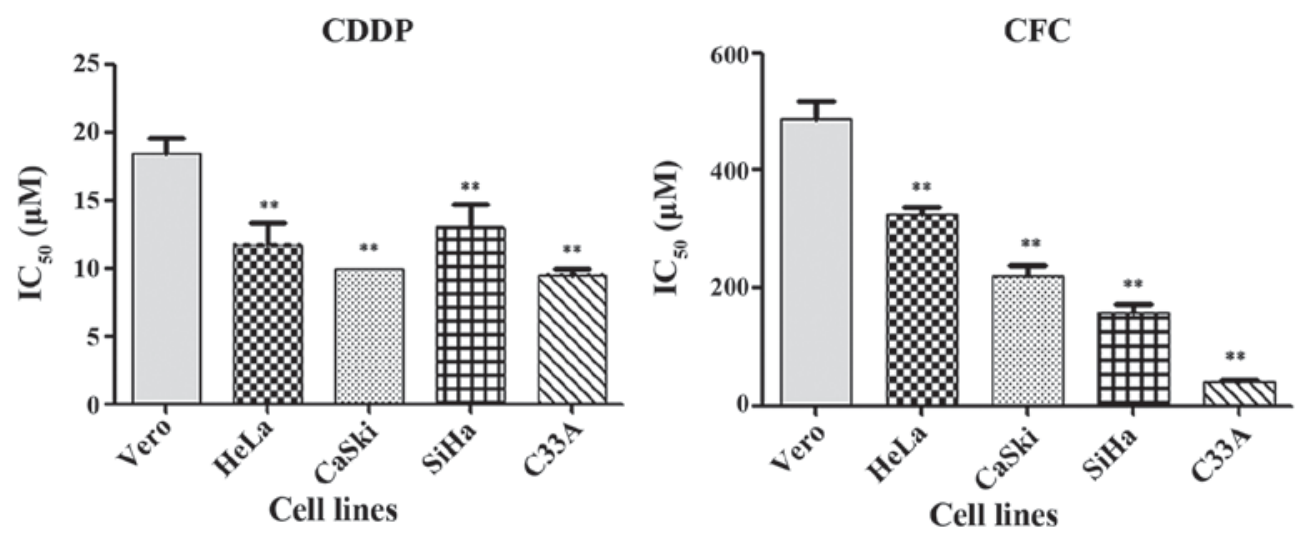

Figure 2. $\mathrm{IC}_{50}$ value of $\mathrm{CDDP}$ and $\mathrm{CFC}$ for $\mathrm{CxCA}$ cell lines and Vero cells at $24 \mathrm{~h} .{ }^{* *} \mathrm{P}<0.01$ compared with Vero cells. CDDP, cisplatin; $\mathrm{CFC}$, caffeic acid; $\mathrm{IC}_{50}$, half-maximal inhibitory concentration.

in Vero, HeLa, CaSki, SiHa and C33A cell lines at $1 \%$ DMSO were $101.09,95.18,96.00,96.47$ and 98.46 , respectively. Therefore, this concentration was safe for experimentation. Prior studies have also reported that the maximum tolerated DMSO percentage in cell culture is $1 \%(\mathrm{v} / \mathrm{v})(22,23)$.

Effects of cisplatin in combination with CFC on cervical cancer cells. The effects of CDDP and CFC in combination on inhibition of HeLa, CaSki and Vero cell viability was determined using isobologram analysis, as described previously (16). The proxies for the combined effects were i) the dose-reduction index (DRI), ii) the combination index (CI) and iii) the dose-effect levels of cell growth inhibition at the $\mathrm{IC}_{50}, \mathrm{IC}_{75}$ and $\mathrm{IC}_{90}$ (Table I). CDDP and $\mathrm{CFC}$ exerted a synergistic effect on HeLa and CaSki cells, but an antagonistic effect on Vero cells (Fig. 3). The highest synergistic effect dose of CDDP and CFC was found in HeLa cells, at the $\mathrm{IC}_{50}, \mathrm{IC}_{75}$ and $\mathrm{IC}_{90}$ gave a CI of $0.88,0.77$ and 0.69 , respectively (Table I). The lowest synergistic effect dose of CDDP-CFC was found in CaSki cells (CI value at $\left.\mathrm{IC}_{50}=0.92\right)$ (Table I).

As a result of the observed synergistic effect of CDDP and $\mathrm{CFC}$, there was a considerable reduction in the DRI. At a dose level corresponding to synergistic drug combinations, the DRI indicated that the $\mathrm{IC}_{50}$ of CDDP could be decreased 2.18-fold (HeLa) and 1.98-fold (CaSki) (Table I).

CDDP, CFC and a combination of CDDP and CFC were tested for their cytotoxicity in CaSki (HPV-16-positive) and HeLa (HPV-18-positive) cell lines, compared with the Vero cell line. CaSki and HeLa cells treated with CDDP and CFC (11 and $300 \mu \mathrm{M}$, respectively) had statistically significant higher percentage of cell inhibition than those treated with CDDP or CFC alone (Fig. 4). No significance in percentage of cell inhibition was found when Vero cells were treated with CDDP-CFC, compared to CDDP and CFC alone.

CDDP-CFC treatment on cervical cancer cells induced apoptosis. CDDP and CFC in combination increased caspase-3, -7 and -9 activity (apoptosis via the intrinsic pathway) to greater degree than using either CDDP or CFC alone (Fig. 5). In Fig. 5A, CDDP and CFC, at 11 and $300 \mu \mathrm{M}$, respectively, significantly activated the expression of the caspase- 3 and -7 in HeLa cells by 4.02- and 6.34-fold compared with CDDP and CFC alone, respectively. Similarly, caspase- 9 expression was significantly increased by CDDP and CFC combination treatment, compared with CDDP or CFC alone.

Similar results were obtained for CaSki cells (Fig. 5B). The increase in caspase- 3 and -7 expression upon treatment with CDDP-CFC, was 1.87-fold higher than CDDP treatment alone and was 2.51-fold higher than CFC treatment alone. Caspase-9 was increased by 2.29 -fold, when treated with a combination of CDDP and CFC, which was significantly higher than that of cells treated with $11 \mu \mathrm{M}$ CDDP (1.88-fold) and treated with CFC (1.26-fold). In addition, CDDP, CFC and CDDP-CFC affected caspase- 8 activity less than caspase-3, -7 and -9 .

In the present study, when a combination of CDDP and CFC was used to treat HeLa and CaSki cells, the expression of caspase- 3 and -7 was increased compared with the expression of caspase- 9 by 7.70 -fold (black bar; Fig. 5A) and by 1.67 -fold (black bar; Fig. 5B), respectively. For HeLa cells treated with CFC, the expression of caspase-3 and -7 was 1.43 -fold higher than the expression of caspase-9 (diagonal bar; Fig. 5A), but in CaSki cells, the expression of caspase- 9 was 0.84 -fold higher than the expression caspase- 3 or -7 (diagonal bar; Fig. 5B).

\section{Discussion}

Chemoresistance is one of the major problems encountered in $\mathrm{CxCa}$ therapy. CDDP is an anticancer drug used for the treatment of $\mathrm{CxCa}$; however, there are numerous side effects and drug resistance is frequently developed $(24,25)$. These issues require the investigation of a novel anticancer agent, potentially derived from natural sources. In the present study, the CxCa CaSki, SiHa, HeLa and C33A cell lines were selected for the experiments owing to their different properties. CaSki and SiHa are HPV-16-positive, whereas HeLa is HPV-18-positive (26). C33A is HPV-negative with mutations to tumor protein p53 (hereafter p53) (27). It was reported that $\mathrm{SiHa}$ cells were more resistant to drug treatment than CaSki cells (28) and that HeLa is more sensitive to CDDP than CaSki (29). C33A is the most responsive of the cell lines examined in the present study to a combination of chemotherapy and radiation (28). Vero cells, isolated from African green monkey kidney epithelial cells, was used as normal control instead of normal human cervical cells due to ethical issues, which is a limitation in the present study. However, previous studies $(30,31)$ have also used Vero cells as control. 
Table I. Dose-response association of CDDP and CFC alone or in combination on HeLa and CaSki cells.

\begin{tabular}{|c|c|c|c|c|c|c|c|c|}
\hline \multirow[b]{2}{*}{ Cell line } & \multirow[b]{2}{*}{ Compound } & \multirow[b]{2}{*}{ Parameter, $\mathrm{r}$} & \multicolumn{3}{|c|}{ CI value } & \multicolumn{3}{|c|}{ DRI value } \\
\hline & & & $\mathrm{IC}_{50}$ & $\mathrm{IC}_{75}$ & $\mathrm{IC}_{90}$ & $\mathrm{IC}_{50}$ & $\mathrm{IC}_{75}$ & $\mathrm{IC}_{90}$ \\
\hline \multirow[t]{3}{*}{ HeLa } & CDDP & 0.93 & & & & 2.18 & 2.28 & 2.21 \\
\hline & $\mathrm{CFC}$ & 0.99 & & & & 2.35 & 3.04 & 4.14 \\
\hline & $\begin{array}{l}\text { CDDP-CFC } \\
(1: 27.3)^{\mathrm{a}}\end{array}$ & 0.99 & 0.88 & 0.77 & 0.69 & & & \\
\hline \multirow[t]{3}{*}{ CaSki } & CDDP & 0.99 & & & & 1.98 & & \\
\hline & $\mathrm{CFC}$ & 0.99 & & & & 2.41 & & \\
\hline & $\begin{array}{l}\text { CDDP-CFC } \\
(1: 18.21)^{\mathrm{a}}\end{array}$ & 0.83 & 0.92 & 1.36 & 2.02 & & & \\
\hline
\end{tabular}

${ }^{a}$ Molar ratio of $\mathrm{IC}_{50}$. CI, combination index; DRI, dose reduction index; CDDP, cisplatin; $\mathrm{CFC}$, caffeic acid; r, correlation coefficient; $\mathrm{IC}_{50}$, half maximal inhibitory concentration.
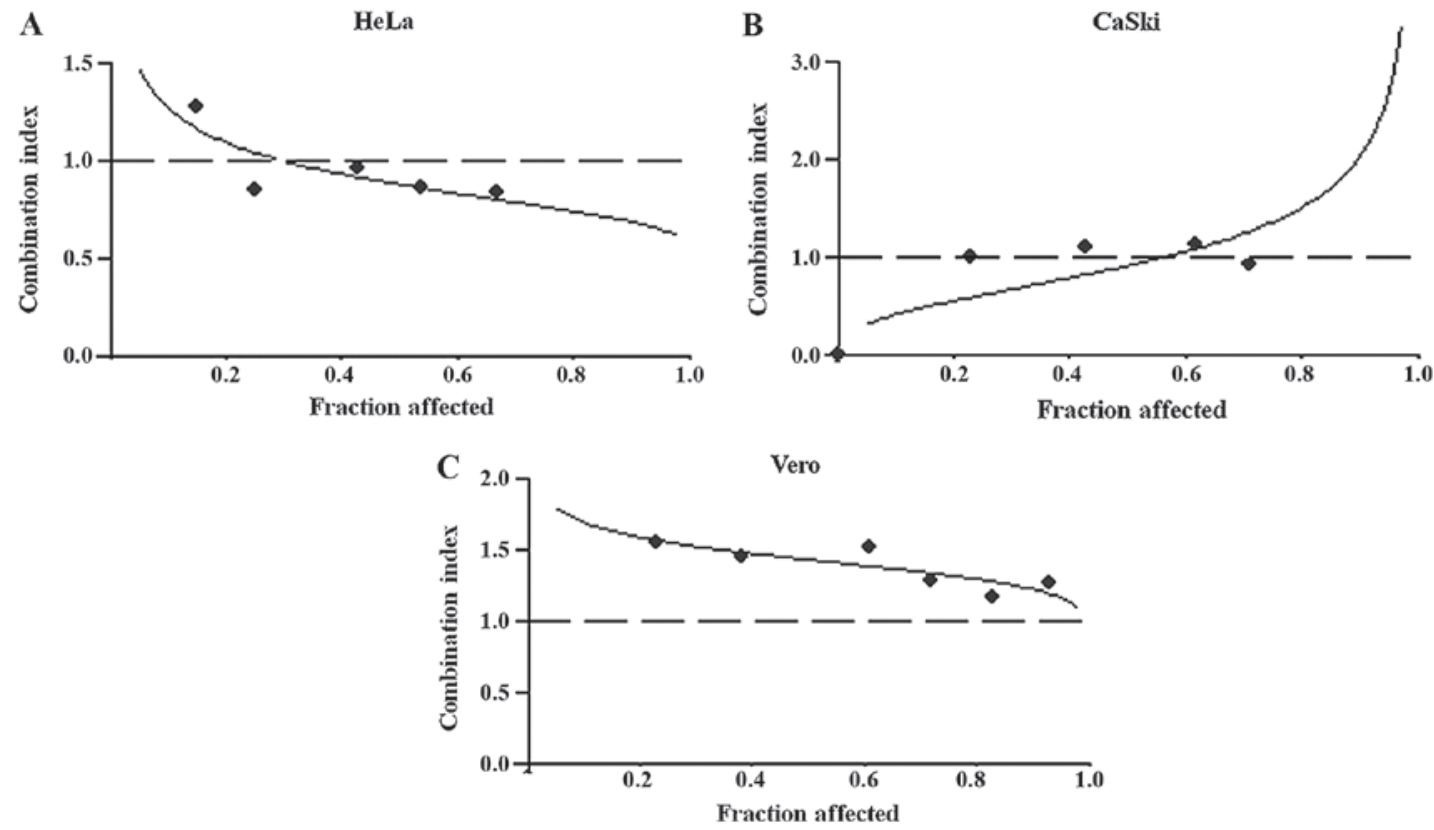

Figure 3. Cytotoxicity of CDDP and CFC in combination on (A) HeLa, (B) CaSki and (C) Vero. The cells were treated with the appropriate concentrations of $\operatorname{CDDP}(2,4,6,8,10,12,14,16,18$ and $24 \mu \mathrm{M})$ and $\operatorname{CFC}(20,50,100,200,400$ and $800 \mu \mathrm{M})$ for $24 \mathrm{~h}$. Plots of the combination index vs. fraction of cells affected were obtained using the median-effect analysis program. Dashed lines indicate a CI of 1. CDDP, cisplatin; CFC, caffeic acid.

DMSO is often used in biological studies for solubilizing drugs or studied compounds.

The combination of phytochemicals with anticancer drugs may result in a synergistic, antagonistic or additive effect in the treatment of cancer. The advantage of synergism is that it can increase the efficacy of therapy; it can also decrease dosage of the compound used which may lead to a reduction in drug toxicity (32). CFC (Fig. 1) is a phytochemical with anticancer properties in $\mathrm{CxCa}$ cells (16). Previous studies revealed that $\mathrm{CFC}$ altered the development of tumors by inhibiting cell growth and modifying the levels of estrogen and insulin-like growth factor I receptors in human breast cancer (33), exhibiting a potent anticancer effect in the human fibrosarcoma HT-1080 cell line (34), alteration of the mitochondrial membrane potential and induction of mitochondrial collapse (35). The results indicated that CFC exhibited lower cytotoxicity than CDDP. In C33A cells, the $\mathrm{IC}_{50}$ value of CFC was 4-fold higher than that of CDDP $(40 \pm 3.21$ vs. $10 \pm 0.50 \mu \mathrm{M})$. The $\mathrm{IC}_{50}$ of CFC and CDDP combined, were obtained for $\mathrm{SiHa}$, CaSki, HeLa and Vero cells as follows: 12, 22, 27 and 27-fold compared to CDDP, respectively. Therefore, CaSki and HeLa cells were selected for assessing the combination of CDDP and CFC, compared with Vero cells.

CDDP and CFC exhibited a higher synergistic effect in HeLa cells than in Caski cell lines (CI value at $\mathrm{IC}_{75}=0.77$ vs. 1.36) (Table I and Fig. 3). A similar study reported that 5-FU in combination with CFC (5-FU and CFC), at the $\mathrm{IC}_{75}$ in $\mathrm{HeLa}$ cells, exhibited a strong synergistic effect (14). The result of DRI (Table I) demonstrated that CDDP and CFC in combination can reduce the effective dose of CDDP for HeLa cells by 


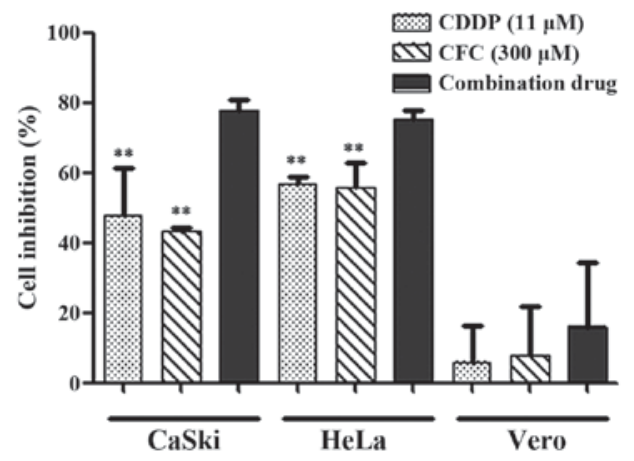

Figure 4. Percentage of cell inhibition of HeLa, CaSki and Vero cells, after treated with various concentrations of drug for $24 \mathrm{~h}$, assessed by sulforhodamine $\mathrm{B}$ assay. ${ }^{* *} \mathrm{P}<0.01$ compared with CDDP and CFC in combination.

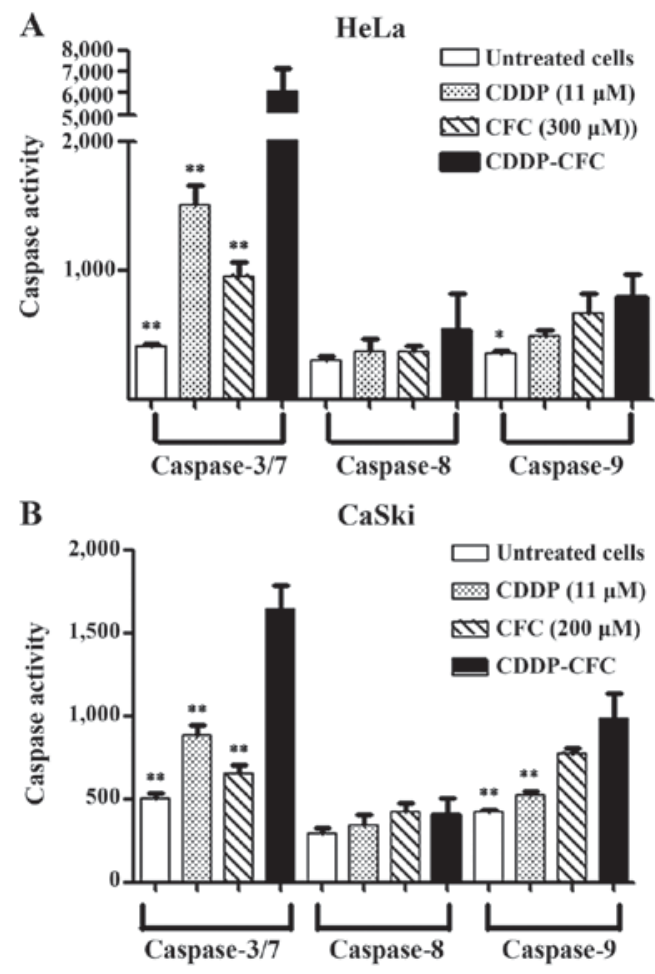

Figure 5. Caspase activation of (A) HeLa (B) CaSki treated with CDDP and CFC alone and CDDP-CFC for $12 \mathrm{~h}$ vs. untreated cells. ${ }^{*} \mathrm{P}<0.05,{ }^{* *} \mathrm{P}<0.01$, compared with CDDP and CFC. CDDP, cisplatin; CFC, caffeic acid.

2.28-fold and 2.21-fold at the $\mathrm{IC}_{75}$ and $\mathrm{IC}_{90}$, respectively, and for CaSki cells by 1.98 -fold at $\mathrm{IC}_{50}$. The findings of the present study indicated that CDDP and CFC in combination increased the cytotoxicity of each agent against the studied cell lines (Fig. 4). The concentrations of CDDP and CFC used in the present study were based on the $\mathrm{IC}_{50}$ values of HeLa cells. CDDP $(11 \mu \mathrm{M}), \mathrm{CFC}(300 \mu \mathrm{M})$ and the same concentration of CDDP combined with CFC could inhibit CaSki and HeLa cell growth; however, no effect was found on Vero cells.

CDDP is often used in combination with natural compounds for enhancing treatment of cancer (6). According to the success of 5-FU and CFC in combination as anticancer agents in HeLa cells (19), the present study assumes that the carboxylic $(-\mathrm{COOH})$ group of $\mathrm{CFC}$ binds with the ammonia $\left(-\mathrm{NH}_{3}\right)$ group in CDDP, forming CDDP-CFC. A previous study revealed that CDDP cross-linked with DNA and altered DNA conformation, leading to DNA damage (36).

The mechanism of action of CDDP and CFC combined in the $\mathrm{CxCa}$ cell lines in the present study was investigated via the apoptotic pathway. Under normal condition, p53 initiates apoptosis in response to cellular stress. Previous reports state that CDDP increased expression of p53 protein in HeLa (37) and CaSki cell lines (38). The $\mathrm{CxCa}$ cells might be more sensitive to CDDP as a result of dormant p53 tumor suppressor pathways (39). These previous studies support the findings of the present study, indicating that the return of $\mathrm{p} 53$ expression may contribute to the chemosensitivity of $\mathrm{CxCa}$ cells. $\mathrm{CDDP}$ and CFC in combination may induce apoptosis by activating DNA damage. The present study is in agreement with that of Ye et al (40), which found that expression of p53 could lead to the induction of apoptosis by activating DNA damage in osteosarcoma cell lines. One limitation of the present study is that the expression of proteins involved in apoptotic pathways was not determined. Measuring the expression of p53, anti-apoptosis [B-cell lymphoma-2 (Bcl-2) and Bcl-xl] and pro-apoptosis proteins (Bcl-associated $\mathrm{X}$ and $\mathrm{Bcl}-2$ homologous antagonist/killer Bak) and should be further investigated to aid elucidation the mechanism of CDDP-CFC-induced apoptosis. The results of the present study (Fig. 5) indicated that CDDP and CFC in combination induced apoptosis via the intrinsic pathway. CDDP and CFC in combination significantly increased the expression of caspase-3, -7 and -9 in HeLa and CaSki cells compared with treatment with either alone. CDDP may induce apoptosis better compared with CFC as the expression of caspase-3 and 7 in HeLa and CaSki cells, which was induced by CDDP, was significantly increased compared with that induced by CFC (Fig. 4). Previous studies reported that CDDP induced apoptosis through the caspase cascade pathway (41) and CFC induced apoptosis via the intrinsic pathway (16). In addition, CDDP, CFC and CDDP and CFC in combination affected caspase- 8 activity less than that of the other caspase (caspase-3,-7 and -9) (Fig. 5). As aforementioned, the expression of caspase- 8 was lower than that of caspase-3, -7 and -9 , as the expression of caspase- $3,-7$ and -9 , but not that of caspase- 8 , was detected at $12 \mathrm{~h}$ following drug treatment.

In conclusion, the results of the present study demonstrated that CDDP and CFC in combination synergistically inhibited the growth of cells and induced apoptosis in HeLa and CaSki cells. The mechanism that is most likely to be behind the efficacy of this treatment is the modulation of apoptosis-regulated expression (i.e. the activation of caspase-3, -7 and -9). No cytotoxicity induced by CDDP and CFC in combination was observed for Vero cells, indicating the feasibility of using CDDP in combination with $\mathrm{CFC}$ as an adjunct to chemotherapy for the management of $\mathrm{CxCa}$. Further in vivo and clinical studies should be conducted to determine the effectiveness of $\mathrm{CDDP}$ and $\mathrm{CFC}$ in combination for the treatment of $\mathrm{CxCa}$.

\section{Acknowledgements}

The present study was supported by the Thailand Research Fund (grant no. RSA5880036) and Khon Kaen University (grant no. 581205). The authors would like to thank the Centre for Research and Development of Medical Diagnostic Laboratories, Faculty of Associated Medical Sciences and 
Graduate School, Khon Kaen University for providing research facilities.

\section{References}

1. Ferlay J, Soerjomataram I, Dikshit R, Eser S, Mathers C, Rebelo M, Parkin DM, Forman D and Bray F: Cancer incidence and mortality worldwide: Sources, methods and major patterns in GLOBOCAN 2012. Int J Cancer 136: E359-E386, 2015.

2. Arbyn M, Castellsagué X, Sanjosé SD, Bruni L, Saraiya M, Bray $\mathrm{F}$ and Ferlay J: Worldwide burden of cervical cancer in 2008. Ann Oncol 22: 2675-2686, 2011.

3. Matsuki M, Takahashi A, Katou S, Takayanagi A, Takagi Y and Kamata K: Pathological complete response to gemcitabine and cisplatin chemotherapy for advanced upper tract urothelial carcinoma: A case report. Nihon Hinyokika Gakkai Zasshi 104: 33-37, 2013 (In Japanese).

4. Pignon JP, Tribodet H, Scagliotti GV, Douillard JY, Shepherd FA, Stephens RJ, Dunant A, Torri V, Rosell R, Seymour L, et al: Lung adjuvant cisplatin evaluation: A pooled analysis by the LACE collaborative group. J Clin Oncol 20: 3552-3559, 2008.

5. Agarwal R and Kaye SB: Ovarian cancer: Strategies for overcoming resistance to chemotherapy. Nat Rev Cancer 3: 502-516, 2003.

6. Dasari S and Tchounwou PB: Cisplatin in cancer therapy: Molecular mechanisms of action. Eur J Pharmacol 740: 364-378, 2014.

7. Wang D and Lippard SJ: Cellular processing of platinum anticancer drugs. Nat Rev Drug Discov 4: 307-320, 2005.

8. Hernandez-Flores G, Ortiz-Lazareno PC, Lerma-Diaz JM, Dominguez-Rodriguez JR, Jave-Suarez LF, Aguilar-Lemarroy Adel C, de Celis-Carrillo R, del Toro-Arreola $S$, Castellanos-Esparza YC and Bravo-Cuellar A: Pentoxifylline sensitizes human cervical tumor cells to cisplatin-induced apoptosis by suppressing NF-kappa B and decreased cell senescence. BMC Cancer 11: 483, 2011.

9. Astolfi L, Ghiselli S, Guaran V, Chicca M, Simoni E, Olivetto E, Lelli G and Martini A: Correlation of adverse effects of cisplatin administration in patients affected by solid tumours: A retrospective evaluation. Oncol Rep 29: 1285-1292, 2013.

10. Kirwan JM, Symonds P, Green JA, Tierney J, Collingwood M and Williams CJ: A systematic review of acute and late toxicity of concomitant chemoradiation for cervical cancer. Radiother Oncol 68: 217-226, 2003.

11. You BR, Moon HJ, Han YH and Park WH: Gallic acid inhibits the growth of HeLa cervical cancer cells via apoptosis and/or necrosis. Food Chem Toxicol 48: 1334-1340, 2010.

12. Karthikeyan S, Kanimozhi G, Prasad NR and Mahalakshmi R: Radiosensitizing effect of ferulic acid on human cervical carcinoma cells in vitro. Toxicol In Vitro 25: 1366-1375, 2011

13. Hussain A, Priyani A, Sadrieh L, Brahmbhatt K, Ahmed M and Sharma C: Concurrent sulforaphane and eugenol induces differential effects on human cervical cancer cells. Integr Cancer Ther 11: 154-165, 2012.

14. Masuda T, Yamada K, Akiyama J, Someya T, Odaka Y, Takeda Y, Tori M, Nakashima K, Maekawa T and Sone Y: Antioxidation mechanism studies of caffeic acid: Identification of antioxidation products of methyl caffeate from lipid oxidation. J Agric Food Chem 56: 5947-5952, 2008.

15. Hwang HJ, Park HJ, Chung HJ, Min HY, Park EJ, Hong JY and Lee SK: Inhibitory effects of caffeic acid phenethyl ester on cancer cell metastasis mediated by the down-regulation of matrix metalloproteinase expression in human HT1080 fibrosarcoma cells. J Nutr Biochem 17: 356-362, 2006.

16. Chang WC, Hsieh CH, Hsiao MW, Lin WC, Hung YC and Ye JC: Caffeic acid induces apoptosis in human cervical cancer cells through the mitochondrial pathway. Taiwan J Obstet Gynecol 49: 419-424, 2010.

17. Singh M, Bhui K, Singh R and Shukla Y: Tea polyphenols enhance cisplatin chemosensitivity in cervical cancer cells via induction of apoptosis. Life Sci 93: 7-16, 2013.

18. Wang H, Provan GJ and Helliwell K: Determination of rosmarinic acid and caffeic acid in aromatic herbs by HPLC. Food Chem 87: 307-311, 2004.
19. Hemaiswarya S and Doble M: Combination of phenylpropanoids with 5-fluorouracil as anti-cancer agents against human cervical cancer (HeLa) cell line. Phytomedicine 20: 151-158, 2013.

20. Pinmai K, Chunlaratthanabhorn S, Ngamkitidechakul C, Soonthornchareon N and Hahnvajanawong C: Synergistic growth inhibitory effects of Phyllanthus emblica and Terminalia bellerica extracts with conventional cytotoxic agents: Doxorubicin and cisplatin against human hepatocellular carcinoma and lung cancer cells. World J Gastroenterol 14: 1491-1497, 2008.

21. Chou TC: Drug combination studies and their synergy quantification using the Chou-Talalay method. Cancer Res 70: 440-446, 2010.

22. Galvao J, Davis B, Tilley M, Normando E, Duchen MR and Cordeiro MF: Unexpected low-dose toxicity of the universal solvent DMSO. FASEB J 28: 1317-1330, 2014

23. Malinin TI and Perry VP: Toxicity of dimethyl sulfoxide on HeLa cells. Cryobiology 4: 90-96, 1967.

24. Rose PG: Chemoradiotherapy for cervical cancer. Eur J Cancer 38: 270-278, 2002.

25. Eifel PJ: Chemoradiotherapy in the treatment of cervical cancer. Semin Radiat Oncol 16: 177-185, 2006.

26. Meissner JD: Nucleotide sequences and further characterization of human papillomavirus DNA present in the CaSki, SiHa and HeLa cervical carcinoma cell lines. J Gen Virol 80: 1725-1733, 1999.

27. Crook T, Wrede D and Vousden KH: p53 point mutation in HPV negative human cervical carcinoma cell lines. Oncogene 6: 873-875, 1991.

28. Saxena A, Yashar C, Taylor DD and Gercel-Taylor C: Cellular response to chemotherapy and radiation in cervical cancer. Am J Obstet Gynecol 192: 1399-1403, 2005.

29. Funaoka K, Shindoh M, Yamashita T, Fujinaga K, Amemiya A and Totsuka Y: High-risk HPV-positive human cancer cell lines show different sensitivity to cisplatin-induced apoptosis correlated with the p21 Waf1/Cip1 level. Cancer Lett 108: 15-23, 1996.

30. Daduang J, Palasap A, Daduang S, Boonsiri P, Suwannalert P and Limpaiboon T: Gallic acid enhancement of gold nanoparticle anticancer activity in cervical cancer cells. Asian Pac J Cancer Prev 16: 169-174, 2015

31. Promraksa B, Daduang J, Khampitak T, Tavichakorntrakool R, Koraneekit A, Palasap A, Tangrassameeprasert R and Boonsiri P: Anticancer potential of Cratoxylum formosum subsp. pruniflorum (Kurz.) gogel extracts against cervical cancer cell lines. Asian Pac J Cancer Prev 16: 6117-6121, 2015.

32. Prabhakara PK, Kumarb A and Doblec M: Combination therapy: A new strategy to manage diabetes and its complications. Phytomedicine 21: 123-130, 2014.

33. Rosendahl AH, Perks CM, Zeng L, Markkula A, Simonsson M, Rose C, Ingvar C, Holly JM and Jernstrom H: Caffeine and caffeic acid lnhibit growth and modify estrogen receptor and insulin-like growth factor I receptor levels in human breast cancer. Clin Cancer Res 21: 1877-1887, 2015.

34. Prasad NR, Karthikeyan A, Karthikeyan S and Reddy BV: Inhibitory effect of caffeic acid on cancer cell proliferation by oxidative mechanism in human HT-1080 fibrosarcoma cell line. Mol Cell Biochem 349: 11-19, 2011.

35. Galati G, Sabzevari O, Wilson JX and O'Brien PJ: Prooxidant activity and cellular effects of the phenoxyl radicals of dietary flavonoids and other polyphenolics. Toxicology 177: 91-104, 2002

36. Onoa GB, Cervantes G, Moreno V and Prieto MJ: Study of the interaction of DNA with cisplatin and other Pd(II) and Pt(II) complexes by atomic force microscopy. Nucleic Acids Res 26: 1473-1480, 1998.

37. Liu Y, Xing H, Han X, Shi X, Liang F, Chen G and Ma D: The mechanism of cisplatin-induced apoptosis in HeLa cells. J Clin Oncol 2: 866-869, 2005.

38. Rao Z, Gao J, Zhang B, Yang B and Zhang J: Cisplatin sensitivity and mechanisms of anti-HPV16 E6-ribozyme on cervical carcinoma CaSKi cell line. Chinese-German J Clin Oncol 11: 237-242, 2012.

39. Putral LN, Bywater MJ, Gu W, Saunders NA, Gabrielli BG, Leggatt GR and McMillan NA: RNA interference against human papillomavirus oncogenes in cervical cancer cells results in increased sensitivity to cisplatin. Mol Pharmacol 68: 1311-1319, 2005.

40. Ye S, Shen J, Choy E, Yang C, Mankin H, Hornicek F and Duan Z: p53 overexpression increases chemosensitivity in multidrug-resistant osteosarcoma cell lines. Cancer Chemother Pharmacol 77: 349-356, 2016.

41. Seki K, Yoshikawa H, Shiiki K, Hamada Y, Akamatsu N and Tasaka K: Cisplatin (CDDP) specifically induces apoptosis via sequential activation of caspase- $8,-3$ and -6 in osteosarcoma. Cancer Chemother Pharmacol 45: 199-206, 2000 